\title{
Indo-Pacific cooperation: what do trade simulations indicate?
}

\author{
Mohammad Masudur Rahman ${ }^{1 *}$ (D, Chanwahn $\mathrm{Kim}^{2}$ and Prabir De ${ }^{3}$
}

\author{
${ }^{*}$ Correspondence: \\ masudbfti@gmail.com \\ ${ }^{1}$ Dept. of Economics, School \\ of Accounting, Finance \\ and Economics (SAFE), \\ The University of Waikato, \\ Hamilton, New Zealand \\ Full list of author information \\ is available at the end of the \\ article
}

\begin{abstract}
This paper investigates the potential economic effect of'Indo-Pacific' regional economic cooperation and compares with the extended CPTPP. The Computable General Equilibrium (CGE) results show that the quadrilateral alliance between the United States, Japan, Australia, and India shows although a substantial economic gain whilst South and East Asia join with the Indo-Pacific cooperation, the economic benefit would be enormous. The findings also indicate that South and East Asian improved trade facilitation could bring huge gain as a large part of Indo-Pacific trade has remained unrealized. The trade transaction cost is one of the major trading barriers prohibiting the growth of Indo-Pacific intra-regional trade. The study reinforces that improvement in infrastructure and connectivity that leads to less trade transportation costs should be a necessary step to realise Indo-Pacific trade potential.
\end{abstract}

Keywords: Indo-Pacific, Trade, Regional integration, Trade facilitation, CGE

JEL Classification: F14, F15, F17

\section{Introduction}

The regional dynamics in the Asia-Pacific region are changing rapidly. China's "Belt and Road Initiative" has gained enormous attention. The USA has withdrawn from the Trans-Pacific Partnership (TPP) Agreement and TPP11, which is now called Comprehensive and Progressive Trans-Pacific Partnership (CPTPP) and has been signed on 8 March 2018 in Chile. The Regional Comprehensive Partnership (RCEP $)^{1}$ has also gained momentum recently. The trilateral free trade agreement (FTA) between China, Japan, and South Korea, the USA and the EU free trade agreement (FTA) (Transatlantic Trade and Investment Partnership-TTIP), ${ }^{2}$ and other regional trade agreements have been emerging due to the deadlock of the WTO's Doha Round. Against this backdrop, a new regional bloc called 'Indo-Pacific' has gained high prominence. Originally, this regional cooperation was aimed to foster a quadrilateral alliance (also known as Quad) between

\footnotetext{
${ }^{1}$ The Regional Comprehensive Economic Partnership (RCEP) has developed amongst 16 countries: the 10 members of ASEAN (Brunei, Cambodia, Indonesia, Laos, Malaysia, Myanmar, the Philippines, Singapore, Thailand, and Vietnam) and the six countries with which ASEAN has existing FTAs-Australia, China, India, Japan, Korea, and New Zealand. RCEP is a significant step in the evolution of trade policy frameworks in East Asia over the past decade. Total population of the region is over 3 billion people and a trade share estimated at around $29 \%$ of global trade, covering GDP of about US\$ 23 trillion (World Bank 2018b)

2 The USA and the EU reaffirmed their commitment to conclude expeditiously a comprehensive and ambitious Transatlantic Trade and Investment Partnership (TTIP) that already accounts for nearly half of global output (EU 2017).
} 
Table 1 Indo-Pacific's share in the World, 2017. Source: Authors' calculation based on WDI (2018a), World Bank

\begin{tabular}{ll}
\hline Indicators & $\begin{array}{l}\text { Share } \\
\text { in World } \\
\text { (\%) }\end{array}$ \\
\hline Surface area & 44 \\
Population & 65 \\
Economic size (GDP, current US\$) & 62 \\
Economic size (GDP, PPP \$ term) & 66 \\
Merchandise trade & 46 \\
\hline
\end{tabular}

the United States, Japan, Australia, and India. However, several South, Southeast, East Asian and Pacific Island economies including Vietnam, New Zealand, Bangladesh, Sri Lanka and some of the Indian Ocean Rim (IOR) countries have shown interests in joining the Indo-Pacific group.

The attributes of the Indo-Pacific are quite appealing. The region comprises at least 38 countries that share $44 \%$ of world surface area and $65 \%$ of world population, and account for $62 \%$ of world-GDP and $46 \%$ of the world's merchandise trade (Table 1). However, the region faces complex challenges in terms of economy, security and the environment. ${ }^{3}$

Most of the Indo-Pacific studies however talk about maritime strategic and geopolitical aspects of the region. David (2012), for example, explores the political and maritime strategic discourse of the Indo-Pacific concept and tries to explore the maritime challenges that are being faced by India in the Indian Ocean and by the USA in the Pacific Ocean. He also discusses the different strategic pathways to meet the challenges. USAID (2015) attempts to inspect the trade relationship link of India with the Southeast and East Asian countries in the context of the Indo-Pacific. Mohan (2017) discusses the relevance of the Indo-Pacific alliance briefly, whilst Singh (2017) attempts to explore the maritime security under the Indo-Pacific context. De (2018), on the other, identifies scope for deepening Indo-Pacific cooperation in connectivity. Scott (2019) evaluates Indonesia's grappling with the Indo-Pacific and concludes that whilst Indonesia certainly is on the rise as an Indo-Pacific actor, its continuing naval weakness undermines Indonesia's "maritime nexus" stance suggesting a closer synergy for Indonesia with the US and Japanese Free and Open Indo-Pacific initiative is suggested. Although most of the literature has argued that the Indo-Pacific cooperation is simply an emerging idea, which is yet to take a formal shape of regional cooperation bloc.

The Computable General Equilibrium (CGE)-based welfare analysis is one of the growing areas for economic analysis of different regional integration including TPP, TTIP, RCEP, and many other free trade agreements. Within the Global Trade Analysis Project (GTAP)based studies, most assume fixed factor supplies and variable factor prices. Gilbert et al. (2018) provide a detailed synthesis of CGE literature and discuss the economic impact of TPP. Kawasaki (2017) and Whittaker et al. (2013) allow for capital accumulation effects. Several papers modify the underlying theory of GTAP. USITC (2016) introduces an elastic labour supply, whilst Akgul et al. (2015) present firm heterogeneity in an exciting proof of

${ }^{3}$ Refer, for example, Chandra and Ghosal (2018). 
concept. Rahman and Ara (2015), Strutt et al. (2015) and Petri and Plummer (2016) attempt to quantify the impact of TPP, TTIP and RCEP on different regions. Cheong and Tongzon (2013) analyse the economic effects of TTP and RCEP and argue that the TPP should be extended for its economic benefit to all Asian countries, including the China. Rollo et al. (2014) evaluate some of the potential effects of TTIP economic integration on low-income countries. Berden et al. (2009) calculate the effects of tariff and NTMs reduction of the proposed TTIP and find that EU GDP may be $0.7 \%$ higher whilst the USA GDP could increase by $0.3 \%$ per year starting 2018 compared to the baseline scenario.

Ciuriak et al. (2016) use a modified version of the GTAP model with recursive dynamics model. The approach is similar to that of the GTAP-Dyn model described in Ianchovichina and McDougall (2001) and utilised in several studies (Cheong and Tongzon 2013; Lee and Itakura 2013). In other innovations, Li and Whalley (2014) employ an Armingtontype model. Roh and Oh (2016) also introduce firm heterogeneity. Strutt et al. (2015) estimate the potential economic of TPP on New Zealand economy using GTAP-Dyn and find that the welfare gains to New Zealand ranging from US\$ 371 million (tariffs only) to US\$ 1.8 billion (tariffs plus NTMs). The above brief review shows that various aspects of TPP, CPTPP, TTIP, and RCEP have been analysed using CGE. However, there is no single research to quantify the impact on Indo-Pacific regional economic cooperation. It would, therefore, be interesting to see the implications of the Indo-Pacific trade deal.

With the above background, the objective of this paper is to make a comparative analysis of likely impact of tariff reduction and trade facilitation under the Indo-Pacific regional integration on various macro- and trade variables. The main aim of the study is to explore different free trade agreements under the canopy of the Indo-Pacific framework. We simulate reductions of tariff and improved trade facilitation in CGE models. This study has the potential to provide profound insights into the currently active policy debate on the regional mega deal. Rest of the paper is arranged as follows. Followed by Introduction in Sect. 1, methodology is briefed in Sect. 2. Section 3 presents the results and conclusions are drawn in Sect. 4.

\section{Methodology and structure of GTAP model}

The most common modelling technique for estimating economic impacts of a trade agreement with economy-wide effects involves the CGE modelling framework of GTAP. The CGE model and GTAP structure are presented in Hertel (1997). ${ }^{4}$ The basic structure of the GTAP database includes industrial sectors, households, governments, and global sectors across countries. Countries and regions in the world economy are linked together through trade. Prices and quantities are simultaneously determined in both factor markets and commodity markets. The main factors of production are skilled and unskilled labour, capital, natural resources and land (Hertel 1997).

Producers operate under constant returns to scale, where the technology is described by the Leontief and CES functions. Two broad categories of inputs are identified: intermediate inputs and primary factors of productions. In the model, firms minimise costs of inputs given their level of output and fixed technology. First, producers use composite units of

\footnotetext{
${ }^{4}$ Refer Hertel (1997) for a full introduction to the database.
} 
intermediate inputs and primary factors in fixed proportions following a Leontief production function. At the second level of the production nest, intermediate input composites are obtained combining imported bundles and domestic goods of the same input-output group.

Trade policy including NTMs can affect the price of traded goods relative to domestically produced goods. As a result, a key relationship for model analysis is the degree of substitution between imported and domestic goods. This key relationship is commonly identified as the Armington elasticity. ${ }^{5}$ It is assumed that domestically produced goods and imports are imperfectly substituted.

Households' behaviour in the model is determined from an aggregate utility function. The aggregate utility is modelled using a Cobb-Douglas utility function with constant expenditure shares. This utility function includes private consumption, government consumption and savings. Current government expenditure goes into the regional household utility function as a proxy for government provision of public goods and services. Private households' consumption is explained by a constant difference elasticity expenditure function.

Domestic support, tariff and NTMs are modelled as ad valorem equivalents. These policies have a direct impact on the production and consumption sectors in the model. The simulation represents what the economy would look like if the policy change or shock had occurred. The difference in the values of the endogenous variables in the baseline and the simulation represents the effect of the policy change. So, the model should be able to provide the effect on trade and production patterns if the trade policy was changed.

This study uses data from GTAP version $9,{ }^{6}$ which has the base year of 2011. Version 9 of the GTAP database covers 57 commodities, 140 regions/countries and eight factors of production. The GTAP framework has strength because of theoretical rigour, its ability to represent direct and indirect interactions amongst all sectors of an economy and precise detailed quantitative results. The strength of the multi-country CGE model is that it incorporates elegantly the features of neoclassical general equilibrium and real international trade models in an empirical framework (Thierfelder et al. 2007). The model's results may be very sensitive to the assumptions and data used.

\subsection{Assumptions of GTAP model}

The main assumption of standard GTAP model is a single regional household with an aggregated utility function. This allocates the regional expenditure across three components that is private expenditure, the government expenditure and savings (Hertel 1997). The model assumes that the regional household sell its endowment commodities to the domestic firms and earn income. The aggregate utility is modelled using a CobbDouglas utility function with constant expenditure shares. The firms, in turn, combine these endowment commodities with intermediate commodities and produce goods for final demand. Producers operate under constant returns to scale, where the technology is described by the Leontief and CES functions. It is assumed that domestically produced goods and imports are imperfectly substituted. The one is a global bank that

\footnotetext{
${ }^{5}$ The constant elasticity of substitution (CES) specification for the trade substitution elasticity is derived from Armington (1969)

${ }^{6}$ Recently GTAP Version 10 has been released.
} 
works as intermediary between global savings and regional investment. The other sector is the trade accounts' and transports' activities. The global bank creates a composite investment good and then supplies this to the regional households to satisfy their saving demands based on a common price for all the savers.

\subsection{Closures}

Model closure statements define which variables are endogenous and which are exogenous. The standard GTAP closure has considered for this analysis. Hertel and Tsigas (1997) and Burfisher (2016) discuss the detailed structure of GTAP closure and how to modify the closure for a particular analysis. To modify the model's standard closure statement, it requires to swap an exogenous variables for an endogenous variable. In this study, we assume that there is perfect competition in all sectors. Production factors, i.e., capital and labour, are assumed to be fully mobile between sectors, whereas land and natural resources are treated as sluggish to move (Burfisher 2016). Fixed balance of trade, that is, for a country, allows domestic savings to adjust to maintain a fixed ratio between trade balance and national income. Government spending is assumed as a constant share of government income. The expected rate of return drives investment as in the standard GTAP model, and total domestic savings is by the sum of private household savings and government budget. Hence, the trade balance is endogenous.

The global bank in the GTAP model uses receipts from the sale of a homogeneous savings commodity to the individual regional households to purchase shares in a portfolio of regional investment goods. The size of this portfolio adjusts to accommodate changes in global savings. Therefore, the global closure in this model is neoclassical (Hertel 1997).

\subsection{The GTAP model for macroeconomic analysis ${ }^{7}$}

The bilateral import tariffs amongst these countries are presented in Table 2. Bilateral average applied import tariffs of Australia and the USA are much lower compared to others. However, Australia imposes comparatively higher tariffs when importing from Japan and India, especially on food grains and processed foods. Japan's import duties on Australia and the USA are also lower, but Japan maintains higher tariffs when importing from India. The USA maintains high tariffs importing from both Japan and India. It is surprising that Indian average applied tariffs on imports from Australia, Japan, and the USA are relatively low, compared to its trade partners.

As mentioned earlier, we use Version 9 of the GTAP database. Data on regions and commodities are aggregated to meet the objectives of this study. The Version 9 of the GTAP database covers 57 commodities, 140 regions/countries and eight factors of production. For the sake of convenience, the 140 regions have been aggregated into 15 regions whereas the 57 sectors have been aggregated into 10 sectors as shown in Appendix.

${ }^{7}$ Refer Hertel (1997) for a full introduction to the database, available at https://www.gtap.agecon.purdue.edu. 


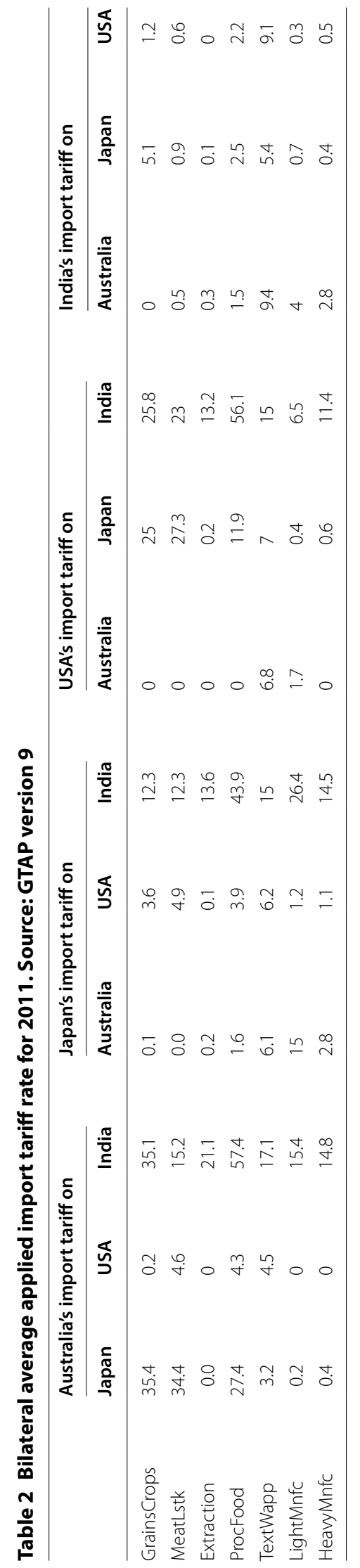


This study has simulated two scenarios: (i) all bilateral tariff eliminations by all its partners under four different scenarios; and (ii) improvement of trade facilitation by $25 \%$ in this region. Here, iceberg trade costs "ams" import-augmenting "technical change" variable has been used to represent trade facilitation. The parameter "ams $(i, r, s)$ " has been introduced to handle bilateral services' liberalisation as well as other efficiency-enhancing measures that serve to reduce the effective price of goods and services' imports. The introduction of this variable facilitates simulation of efficiency improvements such as customs' automation or e-commerce. When ams $(i, r, s)$ is shocked by $25 \%, 25 \%$ more products become available to domestic consumers, given the same level of exports from the source country. To ensure that producers still receive the same revenue on their sales, effective import prices ( $p m s$ ) fall by $25 \%$. However, we simulate following four different scenarios for potential impact analysis of the Indo-Pacific economic cooperation:

\begin{tabular}{ll}
\hline Scenario & Members \\
\hline Indo-Pacific 1 & USA, Japan, India, and Australia FTA \\
Indo-Pacific 2 & Indo-Pacific 1+South Asia + Southeast Asia ${ }^{\text {a }}$ \\
Indo-Pacific 3 & CPTPPc + India + Korea + China \\
Indo-Pacific 4 & Indo-Pacific 1+ASEAN + New \\
& Zealand + Bangladesh + Sri Lanka + Pakistan + China \\
& + Korea + Kenya + Oman + Tanzania + Mozambique \\
& + South Africa + Mauritius + Russia + Chile + Mexico \\
& + Canada \\
& \\
&
\end{tabular}

${ }^{\text {aS }}$ outh Asian market, which consists of Afghanistan, Bangladesh, Bhutan, India, Maldives, Pakistan, Nepal and Sri Lanka, has 1.8 billion population and a total GDP of US\$ 2.37 trillion in 2016.

bSoutheast Asia consists of ten countries: Brunei, Burma, Cambodia, Indonesia, Lao, Malaysia, the Philippines, Singapore, Thailand, and Vietnam. All of these countries are members of the Association of Southeast Asia Nations (ASEAN). Southeast Asia has 622 million population and a total GDP of US\$ 2.35 trillion as on 2017.

${ }^{\mathrm{c}}$ The TPP 11 (CPTPP) has been signed on 8 March 2018 in Chile, which has become a global mega deal.

\section{Analysis of the simulations}

The welfare and other macroeconomic effects of the simulations under 'Indo-Pacific 1 ' are presented in Table 3. The results show that if these four countries (Australia, Japan, India and the USA) remove tariffs, all are expected to experience huge gain in welfare, real GDP and exports. The real GDP could be increased by $0.23 \%$ for India, which amounts to US\$ 2.69 billion in 2014. Indian exports may increase tremendously, accounted for $2.4 \%$ and US\$ 5.7 billion, and at the same time import could be increased by $2.3 \%$, which amounts to about US $\$ 6.8$ billion. On the other, illustrated in Table 4 , the real GDP of Australia, Japan and the USA could be increased by $0.11,0.05$ and $0.01 \%$, respectively, whereas exports may increase by $1.27,0.58$ and $0.56 \%$, respectively.

The reduction of tariffs and non-tariff measures including improved trade facilitation would reduce import cost of its trading partner(s). The exports prices would fall, which could make imports cheaper for its partners. Therefore, a rise in terms of trade (TOT) is significantly contributing to the welfare gain in the region. The allocative 
Table 3 Macroeconomic impact of tariff eliminations under 'Indo-Pacific 1'. Source: Authors' simulation from GTAP version 9

\begin{tabular}{llllc}
\hline Country & $\begin{array}{l}\text { Welfare effect (US\$ } \\
\text { million) }\end{array}$ & $\begin{array}{l}\text { Change in real GDP } \\
(\%)\end{array}$ & $\begin{array}{l}\text { Change in exports } \\
(\%)\end{array}$ & $\begin{array}{l}\text { Change } \\
\text { in imports } \\
(\%)\end{array}$ \\
\hline New Zealand & -144.51 & -0.01 & -0.09 & -0.71 \\
Australia & 2767.05 & 0.11 & 1.27 & 3.25 \\
China & -1788.54 & -0.01 & -0.09 & -0.26 \\
Japan & 5035.89 & 0.05 & 0.58 & 1.44 \\
Korea & -447.34 & -0.01 & -0.02 & -0.19 \\
ASEAN & -683.2 & -0.01 & -0.03 & -0.17 \\
Malaysia & -202.99 & -0.02 & -0.03 & -0.15 \\
Vietnam & -92 & -0.04 & -0.03 & -0.2 \\
South Asia & -117.22 & -0.01 & -0.06 & -0.26 \\
India & 2692.39 & 0.23 & 2.45 & 2.34 \\
Canada & -793.28 & 0 & 0.03 & -0.28 \\
USA & 3686.21 & 0.01 & 0.56 & 0.58 \\
Latin America & -695.98 & 0 & 0.05 & -0.19 \\
EU25 & -1043.17 & 0 & 0.03 & -0.05 \\
Rest of World & -2998.4 & 0 & 0.01 & -0.14 \\
\hline
\end{tabular}

Table 4 Impact of tariff eliminations on sectoral trade under 'Indo-Pacific 1'. Source: Authors' simulation from GTAP version 9

\begin{tabular}{|c|c|c|c|c|c|c|c|c|}
\hline & \multicolumn{2}{|l|}{ India } & \multicolumn{2}{|l|}{ Japan } & \multicolumn{2}{|l|}{ USA } & \multicolumn{2}{|l|}{ Australia } \\
\hline & Import (\%) & Export (\%) & Import (\%) & Export (\%) & Import (\%) & Export (\%) & Import (\%) & Export (\%) \\
\hline GrainsCrops & 10.54 & -0.81 & 11.46 & 8.08 & 2.17 & 5.24 & 7.13 & 4.76 \\
\hline MeatLstk & 16.08 & -2.43 & 10.85 & 13.91 & 2.52 & 11.65 & 8.37 & 18.59 \\
\hline Extraction & -0.45 & 4.26 & -0.05 & 0.56 & 0.1 & 0.41 & 4.03 & 0.94 \\
\hline ProcFood & 2.72 & 0.6 & 3.77 & 5.63 & 0.85 & 4.32 & 2.99 & 9.02 \\
\hline TextWapp & 4.76 & 15.22 & 1.02 & 2.57 & 1.67 & 1.67 & 2.53 & 1.11 \\
\hline LightMnfc & 6.55 & 1.4 & 1.93 & 3.13 & 0.71 & 0.33 & 6.42 & -3.15 \\
\hline HeavyMnfc & 3.9 & 3.09 & 1.41 & -0.18 & 0.55 & 0.45 & 2.08 & 1.37 \\
\hline Util_Cons & 0.97 & -0.08 & 1.3 & -2.37 & 0.39 & -0.6 & 2.21 & -4.39 \\
\hline TransComm & 0.51 & -0.5 & 0.92 & -0.71 & 0.32 & -0.33 & 1.96 & -3.64 \\
\hline OthServices & 0.71 & -1.54 & 0.89 & -1.9 & 0.28 & -0.48 & 1.93 & -4.04 \\
\hline
\end{tabular}

efficiency could increase, which will then lead to higher output and production, especially in food grains, textiles and clothing and heavy industry, thereby expanding real GDP volume. As the imports are higher than its exports in all these four countries, importing the capital machinery for exports may positively affect allocative efficiency.

Light manufacturing and textiles and clothing sector are the primary competitive sectors of India. The import tariff of textiles and clothing is about $12.8 \%$ of Indian partners. Therefore, elimination of tariff of the textiles and clothing sector could increase exports of this sector significantly. At the product level, India's exports may likely go up in cases of textiles and clothing and heavy manufacturing goods. Export of textiles and clothing could be the highest gainer, which may increase to about $15 \%$. Australia's agricultural exports (crops and grains, processed food and meat) could be increased tremendously. 
Table 5 Macroeconomic impact of tariff eliminations and $25 \%$ increase in trade facilitation under 'Indo-Pacific 1'. Source: Authors' simulation from GTAP version 9

\begin{tabular}{llccc}
\hline & $\begin{array}{l}\text { Welfare effect (US\$ } \\
\text { million) }\end{array}$ & $\begin{array}{l}\text { Change in real GDP } \\
(\%)\end{array}$ & $\begin{array}{l}\text { Change in exports } \\
(\%)\end{array}$ & $\begin{array}{l}\text { Change } \\
\text { in imports } \\
(\%)\end{array}$ \\
\hline New Zealand & -862.72 & -0.07 & -1.87 & 0.33 \\
Australia & $25,562.62$ & 1.72 & 5.69 & -0.69 \\
China & $-18,012.7$ & -0.16 & -1.5 & -0.41 \\
Japan & $75,767.8$ & 0.9 & 4.19 & -1.01 \\
Korea & -4992.09 & -0.09 & -1.27 & -0.33 \\
ASEAN & -6648.9 & -0.09 & -1.48 & -0.52 \\
Malaysia & -2184.22 & -0.22 & -1.48 & -0.54 \\
Vietnam & -783.12 & -0.29 & -1.57 & -0.65 \\
South Asia & -859.92 & -0.08 & -1.57 & -0.76 \\
India & $31,429.47$ & 1.87 & 2.21 & -1.09 \\
Canada & -9437.72 & -0.08 & -2.23 & -0.28 \\
USA & $85,086.96$ & 0.42 & 0.26 & -1.1 \\
Latin America & -6668.03 & -0.06 & -1.79 & -0.91 \\
EU25 & $-15,625.4$ & -0.01 & -1.38 & -1.18 \\
Rest of World & $-31,208$ & -0.02 & -1.78 & -0.86 \\
\hline
\end{tabular}

The export of heavy manufacturing sector could be major gainer for the USA. The processed food, meat and light engineering could be major exports' items of Japan.

Some of the trade costs (e.g. the costs of customs' clearance) are not explicitly covered in the GTAP database. How do we then introduce these non-tariff shocks and analyse their likely impact on trade flows? The approach we have taken is to introduce the notion of an "effective price" of commodity $i$, imported from country $r$, at domestic prices in destination markets. The technical coefficient "import-augmenting technical change" (ams) is unobserved, and equal to one in initial equilibrium. Changes in its value capture the impact of trade facilitation measures on the price of imports from a particular exporter. Thus, an increase in "ams" ensures a fall in the effective domestic price of good $i$ exported from country $r$ to country $s$.

The results presented in Table 5 indicate that India would gain enormously if the country reduces trade costs by $25 \%$. Economic welfare could be increased by US\$ 31 billion and real GDP by $1.87 \%$, which is accounted for US\$ 23.5 billion. Real GDP of Australia, Japan and the USA may increase by $1.72,0.9$ and $0.42 \%$, respectively. The results indicate that trade-related transaction cost is one of the major trading barriers prohibiting the growth of Indo-Pacific intra-regional trade. One interesting finding emerges that South and Southeast Asian welfare and GDP would fall due to diverting trade from more efficient partners to less-efficient partners due to the free trade deal.

If Southeast Asian (ASEAN) countries could join the Indo-Pacific block, all these member countries under this regional economic cooperation could gain significantly. Indian GDP and growth could benefit the most. Southeast Asian countries will also be benefitted from the free trade deal. However, if the trade facilitation increases by $25 \%$ amongst these countries, the potential benefit will be enormous. Table 6 presents the simulations results of the macroeconomic impacts. Real GDP of Australia and Japan 
Table 6 Macroeconomic impact of tariff eliminations under 'Indo-Pacific 2: Indo-Pacific $1+$ Rest of South Asia + Rest of ASEAN'. Source: Authors' simulation from GTAP version 9

\begin{tabular}{lclcc}
\hline & $\begin{array}{l}\text { Welfare effect (US\$ } \\
\text { million) }\end{array}$ & $\begin{array}{l}\text { Change in real GDP } \\
(\%)\end{array}$ & $\begin{array}{l}\text { Change in exports } \\
\text { (\%) }\end{array}$ & $\begin{array}{l}\text { Change } \\
\text { i imports } \\
\text { (\%) }\end{array}$ \\
\hline New Zealand & -213.73 & -0.02 & -0.14 & -1.06 \\
Australia & 2775.99 & 0.12 & 1.44 & 3.42 \\
China & -4782.63 & -0.06 & -0.28 & -0.61 \\
Japan & 7708.29 & 0.06 & 0.78 & 2.17 \\
Korea & -1004.13 & -0.02 & -0.07 & -0.43 \\
ASEAN & 5031.04 & 0.17 & 1.42 & 2.7 \\
Malaysia & -314.79 & -0.02 & 0.2 & 0.17 \\
Vietnam & 78.51 & 0.02 & 0.28 & 0.89 \\
South Asia & 1294.74 & 0.32 & 6.71 & 6.75 \\
India & 6640.85 & 0.58 & 5.13 & -0.35 \\
Canada & -966.25 & 0 & 0.05 & 0.71 \\
USA & 3415.48 & 0.01 & 0.95 & -0.38 \\
Latin America & -1188.31 & -0.01 & 0.05 & -0.11 \\
EU25 & -2438.33 & 0 & 0.04 & -0.29 \\
Rest of World & -4902.03 & -0.01 & -0.02 & \\
\hline
\end{tabular}

could increase rapidly. The USA could gain from the deal. Economies of Malaysia and Vietnam will be boosted significantly due to increased trade facilitation.

Tremendous potential exists for increasing trade between South and Southeast Asia, which would provide substantial economic benefits to both regions. South and Southeast Asia are large regions in population and economic terms. South Asia has 1.8 billion population and a total GDP of US\$ 2.91 trillion, whilst Southeast Asia has 622 million population and a total GDP of US\$ 2.8 trillion in 2016 (World Bank 2018a, b). Whilst trade flows between the regions have been increasing substantially over the decade as both regions have embraced more outward-oriented reforms, current trade flows are still far below potential levels.

South Asia's exports to Southeast Asia are only $2.1 \%$ of South Asia's GDP, whereas Southeast Asia's exports to South Asia equal 3.2\% of Southeast Asia's GDP in 2016 (World Bank 2018a, b). According to the Ease of Doing Business of World Bank, trade facilitation of all South Asian countries is overwhelmingly underdeveloped ${ }^{8}$ and most of $^{2}$ the East Asian countries also have similar situation except Singapore and Japan ${ }^{9}$ (World Bank 2018a, b). Therefore, this mega deal could bring enormous benefit to both South and Southeast Asian countries if it could be able to reduce trade-related transaction cost as shown in Table 7.

If India, South Korea and China could enter the mega deal CPTPP, these three countries will be benefitted enormously. Trade benefit of Vietnam and Malaysia could be highest. Our results are consistence with the findings of Gilbert et al. (2018), Cheong and Tongzon (2013), Li and Whalley (2014), Rahman and Ara (2015), and Ciuriak et al.

\footnotetext{
${ }^{8}$ Ease of Doing Business Ranks of all South Asian Countries is over 100 except Bhutan and India.

9 Singapore's rank on the Ease of Doing Business was one and Malaysian and Thailand ranked 24 and 26, respectively. The rest of ASEAN countries ranked over 50.
} 
Table 7 Macroeconomic impact under Indo-Pacific 2: tariff eliminations and $25 \%$ increase in trade facilitation. Source: Authors' simulation from GTAP version 9

\begin{tabular}{llccc}
\hline & $\begin{array}{l}\text { Welfare effect (US\$ } \\
\text { million) }\end{array}$ & $\begin{array}{l}\text { Change in real GDP } \\
(\%)\end{array}$ & $\begin{array}{l}\text { Change in exports } \\
(\%)\end{array}$ & $\begin{array}{l}\text { Change } \\
\text { in imports } \\
(\%)\end{array}$ \\
\hline New Zealand & -1525.68 & -0.13 & -1.15 & -8.43 \\
Australia & $32,700.6$ & 2.65 & 11.2 & 23.94 \\
China & $-42,474.8$ & -0.43 & -2.82 & -6.85 \\
Japan & 110,830 & 1.49 & 3.2 & 20.48 \\
Korea & $-11,997.8$ & -0.22 & -0.75 & -5.21 \\
ASEAN & $80,735.86$ & 5.06 & 10.85 & 20.51 \\
Malaysia & $35,770.2$ & 11.5 & 13.37 & 28.21 \\
Vietnam & $15,567.44$ & 13.9 & 2.19 & 22.29 \\
South Asia & $12,929.77$ & 3.66 & 14.48 & 20.31 \\
India & $49,425.86$ & 3.26 & 15.79 & 16.93 \\
Canada & $-14,326$ & -0.12 & -0.46 & -5.93 \\
USA & $126,847.5$ & 0.7 & 8.91 & 8.58 \\
Latin America & $-12,063.1$ & -0.1 & 0.71 & -3.61 \\
EU25 & $-36,569.8$ & -0.04 & 0.56 & -1.32 \\
Rest of World & $-60,021.7$ & -0.06 & -0.04 & -3.2 \\
\hline
\end{tabular}

Table 8 Macroeconomic of tariff elimination under 'Indo-Pacific 3'. Source: Authors' simulation from GTAP version 9

\begin{tabular}{lclcc}
\hline & $\begin{array}{l}\text { Welfare effect (US\$ } \\
\text { million) }\end{array}$ & $\begin{array}{l}\text { Change in real GDP } \\
(\%)\end{array}$ & $\begin{array}{l}\text { Change in exports } \\
\text { (\%) }\end{array}$ & $\begin{array}{l}\text { Change } \\
\text { in imports } \\
\text { (\%) }\end{array}$ \\
\hline New Zealand & 372.46 & 0.1 & 1.47 & 2.68 \\
Australia & 4183.47 & 0.18 & 2.39 & 5.37 \\
China & 5317.79 & 0.17 & 2.89 & 3.83 \\
Japan & $14,149.59$ & 0.06 & 0.73 & 3.74 \\
Korea & 7635.8 & 0.38 & 2.61 & 5.01 \\
ASEAN & -3114.31 & -0.05 & -0.37 & -1.13 \\
Malaysia & 1720.69 & 0.36 & 1.69 & 3.45 \\
Vietnam & 1580.83 & 2.2 & 6.72 & -0.51 \\
South Asia & -427.58 & -0.04 & -0.16 & 3.91 \\
India & 3072.97 & 0.38 & 4.84 & 1.09 \\
Canada & 1954.32 & 0.07 & 0.64 & -0.69 \\
USA & -5869.1 & 0 & -0.08 & -0.41 \\
Latin America & -1271.39 & -0.01 & 0.07 & -0.14 \\
EU25 & -3152.93 & -0.01 & 0.05 & -0.48 \\
Rest of World & -7617.07 & -0.02 & -0.08 & \\
\hline
\end{tabular}

(2016). Chinese GDP could increase by $0.17 \%$, whereas South Korea and Indian GDP could increase by $0.38 \%$ if these three countries join in the CPTPP (Table 8 ).

The USA will be negatively affected by the deal that is obvious. The other IndoPacific countries could be gained as well. The CGE simulations show that the trade facilitation could be more important compared to tariffs' elimination. The trade facilitation could bring enormous gain across the region. Table 9 shows the simulations results, which indicate that the global welfare also could be increased enormously. 
Table 9 Macroeconomic impact of tariff elimination and 25\% increase in trade facilitation under Indo-Pacific 3. Source: Authors' simulation from GTAP version 9

\begin{tabular}{lcccl}
\hline & $\begin{array}{l}\text { Welfare effect (US\$ } \\
\text { million) }\end{array}$ & $\begin{array}{l}\text { Change in real GDP } \\
(\%)\end{array}$ & $\begin{array}{l}\text { Change in exports } \\
(\%)\end{array}$ & $\begin{array}{l}\text { Change } \\
\text { in imports } \\
(\%)\end{array}$ \\
\hline New Zealand & 6382.73 & 3.41 & 11.06 & 22.36 \\
Australia & $40,844.5$ & 2.74 & 10.8 & 28.85 \\
China & $140,357.3$ & 3.58 & 16.03 & 19.96 \\
Japan & $117,916.8$ & 1.52 & 3.2 & 23.45 \\
Korea & $83,731.05$ & 5.5 & 11.72 & 26.69 \\
ASEAN & $-20,919.7$ & -0.28 & -3.14 & -8.34 \\
Malaysia & $28,306.52$ & 8.89 & 9.77 & 21.05 \\
Vietnam & $15,659.16$ & 17.8 & 5.95 & 24 \\
South Asia & -1520.01 & -0.19 & -1.3 & -3.22 \\
India & $34,130.96$ & 2.44 & 14.97 & 13.76 \\
Canada & $25,541.9$ & 1.4 & 3.04 & -4.4 \\
USA & $-39,889.7$ & -0.03 & -1.83 & -2.75 \\
Latin America & -9862.62 & -0.09 & 0.18 & -0.93 \\
EU25 & $-19,052.4$ & -0.05 & 0.07 & -3.4 \\
Rest of World & $-72,676.3$ & -0.12 & -0.31 & \\
\hline
\end{tabular}

The USA will face tremendous negative impact due to trade diversion or preference erosion.

Tables 10 and 11 show the macroeconomic scenario under Indo-Pacific 4. If the Asia Pacific countries could join the Indo-Pacific trade deal, gain from the economic cooperation would be enormous under both tariff reduction and improved trade facilitation. The Canada, Mexico, Chile may reduce their welfare gain due to preference erosion. However, improved trade facilitation would offset that and could result in tremendous benefit in the region.

Table 12 provides comparative welfare analysis of the four scenarios. The results show that the overall impact of tariff elimination and trade facilitation is enormous. The welfare gain of tariff elimination under 'Indo-Pacific 1' countries is only US\$ 14.1 billion. However, if we could reduce trade-related cost by $25 \%$ and with the removal of tariff, the welfare gain would be US\$ 217 billion. Under Indo-Pacific scenario 2, the welfare impact is also similar, and the benefits of trade facilitation are enormous from US\$ 26 billion to US\$ 464 billion of the member countries. However, if India, China, and South Korea join in the CPTPP, the welfare gain would be much higher. Trade-GDP ratio of these countries is higher compared to other members. Therefore, the economic benefit would be higher, and trade diversion benefit would also be higher. Out of the four scenarios, tariff elimination and trade facilitation under Indo-Pacific 4 may generate an additional US\$ 1.12 trillion welfare gain for the Indo-Pacific member countries.

\section{Concluding remarks}

The Indo-Pacific concept has emerged recently. This study investigates the potential economic benefit of Indo-Pacific regional cooperation. We simulate four different scenarios. We not only eliminate tariff, but also simulate if we could reduce the importrelated trade costs by $25 \%$ in the region and explore the potential economic gain under the regional economic cooperation. 
Table 10 Macroeconomic impact of tariff elimination under 'Indo-Pacific 4'. Source: Authors' simulation from GTAP version 9

\begin{tabular}{lclcc}
\hline & $\begin{array}{l}\text { Welfare effect (US\$ } \\
\text { million) }\end{array}$ & $\begin{array}{l}\text { Change in real GDP } \\
(\%)\end{array}$ & $\begin{array}{l}\text { Change in exports } \\
\text { (\%) }\end{array}$ & $\begin{array}{l}\text { Change } \\
\text { i imports } \\
\text { (\%) }\end{array}$ \\
\hline Indo-Pacific-1 & $40,215.92$ & 0.08 & 4.43 & 4.76 \\
New Zealand & -150.53 & -0.01 & 1.03 & 0.56 \\
China & $10,175.66$ & 0.24 & 2.49 & 3.24 \\
Korea & -417.01 & 0.1 & 1.49 & 1.78 \\
ASEAN & 2471.45 & 0.11 & 0.95 & 1.45 \\
Pakistan & 281.11 & 0.19 & 4.05 & 3.38 \\
Sri Lanka & 122.73 & 0.2 & 2.42 & 4.23 \\
Bangladesh & 168.64 & 0.08 & 5.24 & -0.21 \\
Canada & -2810.68 & 0.04 & 0.69 & -0.85 \\
Mexico & -2373.83 & 0 & 0.53 & 0.12 \\
Chile & -81.72 & 0 & 0.24 & -0.3 \\
EU25 & $-10,728.26$ & -0.01 & 0.13 & 1.11 \\
Kenya & -55.88 & 0.11 & 2.77 & 0.92 \\
Tanzania & 5.64 & 0.15 & 1.61 & 0.57 \\
Mozambique & -5.53 & 0.03 & 0.44 & -0.35 \\
Mauritius & -18.94 & -0.02 & 0.14 & 3.17 \\
South Africa & 619.89 & 0.14 & 2.11 & 1.3 \\
Oman & -25.36 & 0.06 & 0.77 & -0.8 \\
Rest of World & $-11,289.22$ & -0.02 & -0.08 & \\
\hline & & & & \\
\hline
\end{tabular}

Table 11 Macroeconomic impact of tariff elimination and $25 \%$ increase in trade facilitation under Indo-Pacific 4. Source: Authors' simulation from GTAP version 9

\begin{tabular}{lcccc}
\hline & $\begin{array}{l}\text { Welfare effect (US\$ } \\
\text { million) }\end{array}$ & $\begin{array}{l}\text { Change in real GDP } \\
(\%)\end{array}$ & $\begin{array}{l}\text { Change in exports } \\
(\%)\end{array}$ & $\begin{array}{l}\text { Change } \\
\text { in imports } \\
(\%)\end{array}$ \\
\hline Indo-Pacific-1 & $713,565.6$ & 2.73 & 23.61 & 29.88 \\
New Zealand & 4202.43 & 2.76 & 9.68 & 12.63 \\
China & $131,121.1$ & 3.15 & 11.95 & 13.73 \\
Korea & $38,371.2$ & 3.71 & 4.55 & 5.98 \\
ASEAN & $61,082.34$ & 4.08 & 4.87 & 6.79 \\
Pakistan & 3317.69 & 1.6 & 2.09 & 5.52 \\
Sri Lanka & 1860.56 & 4.29 & -4.7 & 5.59 \\
Bangladesh & 1520.84 & 1.8 & 8.39 & 7.08 \\
Canada & $98,426.02$ & 5.28 & 15.59 & 27.64 \\
Mexico & $55,878.04$ & 3.91 & 11.14 & 24.26 \\
Chile & 4010.65 & 2.1 & 5.29 & -3.25 \\
EU25 & $-102,284$ & -0.1 & 1.18 & 2.31 \\
Kenya & 938.05 & 2.71 & -1.08 & -0.72 \\
Tanzania & 223.86 & 1.77 & 2.64 & -2.69 \\
Mozambique & 96.8 & 2.46 & -0.27 & 4.78 \\
Mauritius & 326.51 & 4.18 & 2.82 & 3.48 \\
South Africa & 1019.27 & -0.09 & 3.29 & -1.25 \\
Oman & 852.91 & 3.65 & 2.92 & -7.83 \\
Rest of World & $-147,785$ & -0.18 & 0.39 & \\
\hline & & & & \\
\hline
\end{tabular}


Table 12 A comparative welfare analysis (US\$ billion). Source: Authors' simulation from GTAP version 9

\begin{tabular}{lcc}
\hline & Only tariff elimination & $\begin{array}{c}\text { Tariff elimination } \\
\text { plus trade } \\
\text { facilitation }\end{array}$ \\
\hline Indo-Pacific 1 & 5.174 & \\
World & 14.181 & 120.563 \\
Indo-Pacific members & -9.007 & 217.846 \\
Non-members & & -97.282 \\
Indo-Pacific 2 & 11.134 & \\
World & 26.866 & 285.828 \\
Indo-Pacific members & -15.731 & 464.807 \\
Non-members & & -178.978 \\
Indo-Pacific 3 & 18.535 & 328.95 \\
World & 39.615 & 486.488 \\
Indo-Pacific members & -21.079 & -157.537 \\
Non-members & & 866.745 \\
Indo-Pacific 4 & 26.104 & 1116.814 \\
World & 48.121 & -250.068 \\
Indo-Pacific members & -22.017 & \\
Non-members & & \\
\hline
\end{tabular}

The CGE results illustrate that the quadrilateral alliance between the United States, Japan, Australia, and India shows a positive economic gain. However, if South and Southeast Asia join in the Indo-Pacific, the economic benefit would be enormous. As a large part of Indo-Pacific trade has remained unrealised, the findings of this study also indicate that improved trade facilitation could bring huge gain to this region. The trade transaction cost is one of the major trading barriers prohibiting the growth of IndoPacific intra-regional trade. The study reinforces that improvement in infrastructure and connectivity leading to reduce trade transportation costs should be a necessary step in order to realise the Indo-Pacific trade potential. The economic gain under extended СРТPP is also enormous amongst the region. If Korea, China, and India join in the CPTPP, the economic gain of these countries would be enormously high.

The Indo-Pacific could become a powerful regional block if the South and Southeast Asia could be linked through the connectivity, maritime link, improved trade facilitation and other networks that would reduce trade costs. If the vision of the economic corridor gains momentum, it will need to be enhanced by building greater physical infrastructure, more regulatory trade architecture as well as human and digital connectivity.

However, the results from CGE study may be very sensitive to the assumptions and data used. Almost all CGE exercises include a sensitivity analysis to obtain a range of results based on different assumptions and the modelling process. The sectoral or country specific study on Indo-Pacific regional economic cooperation would be further research.

Acknowledgements

The earlier version of this paper was presented at the Third Asian Consortium on South Asian Studies (ACSAS) on November 22-23, 2019, Singapore, organised by National University of Singapore (NUS), Singapore and in the International Conference on Great Transition in India: Prospects and Challenges on October 10-11, 2019, Seoul, organised by Hankuk University of Foreign Studies, Seoul, Korea. Views expressed by authors are their own. Usual disclaimers apply. 
Authors' contributions

All authors have equally contributed to conceptualising and designing of the research, the process of data collection and data analysis as well as drafting and revision of the manuscript. All authors read and approved the final manuscript.

\section{Authors' informations}

Dr. Mohammad Masudur Rahman has more than 14 years of research, consulting and teaching experience in New Zealand, China, Japan, Vietnam, Korea and Bangladesh. Recently, Dr. Rahman completed two projects funded by World Bank where he contributed to developing international trade portal for Vietnam and Bangladesh government. The main research focus of Dr. Rahman is regional integration, trade facilitation, non-tariff measures and gravity and CGE modelling.

Dr. Prabir De is a Professor at the Research and Information System for Developing Countries (RIS). He is also the Coordinator of ASEAN-India Centre (AIC) at RIS. De works in the field of international economics and has research interests in international trade and development. He is the Editor of The South Asia Economic Journal, published by Sage.

Professor Chanwanh Kim is Director, School of Business at Hankuk University of Foreign Studies, Seoul, Korea. He has been conducting policy research for the Government of Korea and several international organisations. He is the Editor of Journal of India and Asian Studies published by World Scientific (Singapore).

\section{Funding}

This study was supported by Hankuk University of Foreign Studies Research Fund of 2018 and National Research Foundation of Korea Grant Funded by the Korean Government (NRF-2017S1A6A3A02079749).

\section{Availability of data and materials}

The dataset that used in this study is available in and bought from the GTAP database version 9 of Perdue University (https://www.gtap.agecon.purdue.edu/databases/v9/default.asp), USA.

\section{Competing interests}

The authors declare that they have no competing interests.

\section{Author details}

1 Dept. of Economics, School of Accounting, Finance and Economics (SAFE), The University of Waikato, Hamilton, New Zealand. ${ }^{2}$ Department of Indian and ASEAN Studies, Graduate School of International and Area Studies, Hankuk University of Foreign Studies, Seoul, South Korea. ${ }^{3}$ Research and Information System for Developing Countries (RIS), New Delhi, India.

\section{Appendix}

See Table 13.

Table 13 Regional and commodity aggregation of GTAP database. Source: GTAP version 9

\begin{tabular}{|c|c|c|c|c|c|}
\hline SL & Aggregated region & GTAP region & SL & $\begin{array}{l}\text { Aggregated } \\
\text { commodities }\end{array}$ & GTAP commodities \\
\hline 1 & China & China & 1 & Grains crops (9 products) & $\begin{array}{l}\text { pdr wht gro } v \_f \text { osd } c \_b \\
\text { pfb ocr pcr }\end{array}$ \\
\hline 2 & USA & United States of America & 2 & Meat Lstk (6 products) & $\mathrm{ctl}$ oap rmk wol cmt omt \\
\hline 3 & EU25 & EU 25 Countries & 3 & Extraction (6 products) & frs fsh coa oil gas omn \\
\hline 4 & Canada & Canada & 4 & ProcFood (5 products) & vol mil per sgr ofd \\
\hline 5 & New Zealand & New Zealand & 5 & Text Wapp (2) & tex wap \\
\hline 6 & Australia & Australia & 6 & LightMnfc (7) & $\begin{array}{l}\text { lea lum ppp fmp mvh } \\
\text { otn omf }\end{array}$ \\
\hline 7 & Japan & Japan & 7 & HeavyMnfc (7) & $\begin{array}{l}\text { P_c crp nmm i_s nfm } \\
\text { ele ome }\end{array}$ \\
\hline 8 & ASEAN & $\begin{array}{l}\text { ASEAN except Malaysia } \\
\text { and Vietnam }\end{array}$ & 8 & Util_Cons (4) & ely gdt wtr cns \\
\hline 9 & Malaysia & Malaysia & 9 & Trans Comm (5) & trd otp wtp atp cmn \\
\hline 10 & Viet Nam & Vietnam & 10 & Oth Services (6) & ofi isr obs ros osg dwe \\
\hline 11 & South Asia & South Asia except India & & & \\
\hline 12 & India & India & & & \\
\hline 13 & Korea & Korea & & & \\
\hline 14 & Latin America & All Latin America & & & \\
\hline 15 & Rest of the world & $\begin{array}{l}\text { Rest of countries in } \\
\text { the World of GTAP } \\
\text { database }\end{array}$ & & & \\
\hline
\end{tabular}


Received: 10 September 2019 Revised: 19 March 2020 Accepted: 29 June 2020

Published online: 06 July 2020

\section{References}

Akgul Z, Villoria NB, Hertel TW (2015) Introducing firm heterogeneity into the GTAP model with an illustration in the context of the trans-Pacific partnership agreement. Mimeo, Department of Agricultural Economics, Purdue University. https://www.gtap.agecon.purdue.edu/resources/res_display.asp?RecordID $=4445$

Armington PS (1969) A theory of demand for products distinguished by place of production. IMF Staff Pap. 16(1): 159-178. https://ideas.repec.org/a/pal/imfstp/v16y1969i1p159-178.html

Berden KG, Francois J, Tamminen S, Thelle M, Wymenga P (2009) Non-tariff measures in EU-US trade and investmentan economic analysis, ECORYS report prepared for the European Commission, Reference OJ 2007/S180-219493, Nederland BV

Burfisher ME (2016) Introduction to computable general equilibrium models, 2nd edn. Cambridge University Press, Cambridge

Chandra S, Ghoshal B (eds) (2018) The Indo-Pacific axis: peace and prosperity or conflict?. Routledge, New Delhi

Cheong I, Tongzon J (2013) Comparing the economic impact of the trans-Pacific partnership and the regional comprehensive economic partnership. Asian Econ Pap 12(2):144-164

Ciuriak D, Dadkhah A, Xiao J (2016) Taking the measure of the TPP as negotiated, Working paper, Ciuriak Consulting

David S (2012) The "Indo-Pacific" —new regional formulations and new maritime frameworks for US-India strategic convergence. Asia-Pac Rev 19(2):85-109. https://doi.org/10.1080/13439006.2012.738115

De P (2018) Indo-Pacific cooperation: some thoughts on connectivity. In: Mansingh L, Mudgal AK, Singh UB (eds) Purbasa: East Meets East: synergising the north-east and eastern India with the Indo-Pacific. Pentagon Press, New Delhi

EU (2017) Transatlantic trade and investment partnership (TTIP)—challenges and opportunities, European Parliament. http://www.europarl.europa.eu/legislative-train/theme-reasonable-and-balanced-trade-agreement-with-the-unite d-states/file-ttip-pharmaceuticals-1. Accessed 15 July 2018

Gilbert J, Furusawa T, Scollay R (2018) The economic impact of the trans-Pacific partnership: what have we learned from CGE simulation? World Econ 41:831-865. https://doi.org/10.1111/twec.12573

Hertel TW (ed) (1997) Global trade analysis: modelling and applications. Cambridge University Press, Cambridge

Hertel TW, Tsigas ME (1997) Structure of GTAP. In: Hertel TW (ed) Global trade analysis: modeling and applications. Cambridge University Press, Cambridge

lanchovichina E, McDougall R (2001) Theoretical structure of dynamic GTAP. Global Trade Analysis Project (GTAP), Technical paper no 17

Kawasaki K (2017) Emergent uncertainty in regional integration: economic impacts of alternative RTA scenarios. GRIPS discussion paper series 16-28. National Graduate Institute for Policy Studies, Tokyo, Japan

Lee H, Itakura K (2013) What might be a desirable FTA path towards global free trade for Asia-Pacific Countries? Working paper, Osaka University

Li C, Whalley J (2014) China and the trans-Pacific partnership: a numerical simulation assessment of the effects involved. World Econ 37(2):169-192

Mohan RC (2017) Donald Trump's 'Indo-Pacific' and America's-India Conundrum, ISAS insights No. 476, Institute of South Asian Studies, National University of Singapore

Petri PA, Plummer MG (2016) The economic effects of the trans-Pacific partnership: new estimates, Peterson Institute for International Economics, Working paper 16-2

Rahman MM, Ara LA (2015) TPP, TTIP, and RCEP: implications for South Asian economies. South Asia Econ J 16(1):27-45

Roh J-W, Oh K (2016) A study of the economic impacts of the TPP on Korea: Armington and Melitz model. J Korea Trade 20(1):35-46

Rollo J, Holmes P, Henson S, Mendez Parra M, Ollerenshaw S, Lopez Gonzalez J, Cirera X, Sandi M (2014) Potential effects of the proposed transatlantic trade and investment partnership on selected developing countries. CARIS, University of Sussex, Brighton

Scott D (2019) Indonesia Grapples with the Indo-Pacific: Outreach, Strategic Discourse, and Diplomacy. J Curr SE Asian Aff 38(2):194-217. https://doi.org/10.1177/1868103419860669

Singh A (2017) A'rules-based' maritime order in the Indo-Pacific: aligning the building blocks, Regional Outlook paper no 57, Griffith Asia Institute, Griffith University

Strutt A, Minor P, Rae A (2015) A dynamic computable general equilibrium analysis of the trans-Pacific partnership agreement: potential impacts on the New Zealand economy, Report prepared for the New Zealand Ministry of Foreign Affairs and Trade

Thierfelder K, Robinson S, Korman V, Kearney M, Go DS, Essama-Nssah B (2007) Economy-wide and distributional impacts of an oil price shock on the South African economy. Policy research working paper series 4354, The World Bank

USAID (2015) Indo-Pacific economic corridor (IPEC) Phase 1: coordinated regional trade analysis, assessment report, United States Agency for International Development (USAID). https://banyanglobal.com/wp-content/uploa ds/2017/06/Indo-Pacific-Economic-Economic-Corridor.pdf

USITC (2016) Trans-Pacific partnership agreement: likely impact on the US economy and specific industry sectors. United States International Trade Commission (USITC), Publication Number 4607

Whittaker H, Scollay R, Gilbert J (2013) TPP and the future of food policy in Japan, New Zealand Asia Institute, Working paper 13-01 
World Bank (2018a) World development indicators. Washington DC. http://data.worldbank.org.ezproxy.waikato.ac.nz/. Accessed 17 July 2018

World Bank (2018b) Ease of doing business 2018. Washington, DC. http://www.doingbusiness.org/en/rankings. Accessed 29 May 2018

\section{Publisher's Note}

Springer Nature remains neutral with regard to jurisdictional claims in published maps and institutional affiliations.

Submit your manuscript to a SpringerOpen ${ }^{\circ}$ journal and benefit from:

- Convenient online submission

- Rigorous peer review

- Open access: articles freely available online

- High visibility within the field

Retaining the copyright to your article

Submit your next manuscript at $\gg$ springeropen.com 